\title{
STRATEGI PEMBELAJARAN BAHASA JAWA \\ DI SMP MUHAMMADIYAH BOARDING SCHOOL YOGYAKARTA
}

\author{
Suwarna, Panca Aditya Subekti \\ Universitas Negeri Yogyakarta. \\ subektipancaaditya@gmail.comsuwarnajawa@gmail.com
}

\begin{abstract}
ABSTRAK
Penelitian ini bertujuan untuk mendeskripsikan strategi pembelajaran bahasa Jawa dan faktor yang melatarbelakangi penggunaan berbagai macam strategi tersebut sehingga menjadikan pembelajaran bahasa Jawa di SMP Muhammdiyah Boarding School(MBS)Yogayakarta berbeda dari sekolah umum lainnya. Penelitian ini adalah penelitian kualitatif. Sumber data penelitian adalah siswa dan guru bahasa Jawa dengan objek penelitian strategi pembelajaran bahasa Jawa di sekolah tersebut. Teknik pengumpulan data dengan observasi, wawancara, dokumentasi dan angket. Keabsahan data dengan cara uji kredibilitas, transferabilitas, dan reabilitas. Teknik analisis data menggunakan reduksi data, penyajian data dan pengambilan kesimpulan. Strategi yang digunakan dalam kegiatan pembelajaran berdasarkanposisi bahasa Jawa sebagai bahasa kedua dan bahasa asing di MBS, ada strategimemori, kognitif,kompensasi, meta-kognitif, afektif, dan sosial. Faktor pemilihan strategi tersebut antara lain: tujuan pembelajaran, siswa, kurikulum, sarana prasarana, materi dan waktu, akses informasi dan komunikasi Kata kunci: Strategi Pembelajaran, Bahasa ke Dua dan Asing, Basa Jawa, Boarding School
\end{abstract}

\begin{abstract}
This study aims to determine the strategy used in the Javanese language learning in SMP Muhammadiyah Yogyakarta Boarding School (MBS) and factors behind the selection of strategies. This study is a qualitative research. Data sources were students and teachers with the Javanese language object Javanese language learning strategy research at the school. The technique of collecting data was through observation, interviews, documentation and questionnaire. Validity of test data was by credibility, transferability and reliability. Data were analyzed using data reduction, data presentation and conclusions. The strategy used in the learning activities based on the position of the Javanese language as a second language and foreign languages in MBS, there are memory strategies, cognitive, compensation, meta-cognitive, affective, and social.The strategy selection factors islearning objectives, students, curriculum, facilities, materials and time, access to information and communication.
\end{abstract}

Keyword : Learning Strategy, Second and Foreign Languages, Javanese language, Boarding School

\section{PENDAHULUAN}

Perda nomor 5 tahun 2011 Pemerintah Provinsi Daerah Istimewa Yogyakarta (DIY) tentang penyelenggaraan pendidikan berbasis budaya, sebagi perhatian pemerintah DIY untuk perkembangan pendidikan di sekolah. Pendidikan berbasis 
budaya ini salah satunya dengan pembelajaran bahasa daerah. Ketetapan ini kemudian disusul dengan Peraturan Gubernur DIY No 64 tahun 2013 yang menjelaskan bahawa bahasa Jawa dijadikan sebagai mulok wajib di sekolah atau madrasah. Dengan adanya peraturan daerah dan peraturan Gubernur DIY tersebut membuat guru menjadi harus semakin kreatif dalam menyampaikan pembelajaran, apalagi dengan kondisi siswa yang berlatar belakang bahasa Jawa bukan sebagai bahasa Ibu. Hal tersebut juga menjadi permasalah dalam pembelajaran bahasa Jawa di SMP Muhammadiyah Boarding School Yogyakarta

Badruzzaman (2015,p.90) mengatakan bahwa SMP Muhammadiyah Boarding School Yogyakarta adalah sekolah berbasis pesantren modern yang mengusung dua kurikulum yaitu kurikulum umum dan kurikulum pondok yang terkemas menjadi satu bernaung dalam KTSP. Sekolah dengan berbasis agama ini pasti memiliki konsep dan tujuan yang tidak semata-mata hanya sekedar mengikuti kemajuan teknologi. Boarding school adalah lembaga yang kegiatannya, meliputi pendidikan yang aktivitas siswa dan guru bisa berinteraksi selama 24 jam saetiap harinya dengan kagiatan ini adalah gabungan antara pendidikan agama dan pendidikan umum. Program yang diadakan di boarding school ini untuk mencapai tujuan pembelajaran yang berbeda konsepnya dengan sekolah umum, karena ada aturan baku yang harus selaras dengan sekolah reguler, dimana program itu juga harus disesuaikan dengan program boarding school.Karakteristik boarding school bisa dilihat dari aspek-aspek kurikulum dan metode pendidikan dengan alokasi waktu yang seimbang antara pendidikan agama untuk membentuk watak dan pribadi siswa dengan kurikulum umum untuk mengikuti perkembangan teknologi serta aspek kedisiplinan.Dengan adanya permasalahan pembelajaran bahasa Jawa di MBS guru harus memikirkan strategi apa yang harus digunakan dalam pembelajaran agar bisa memenuhi kurikulum yang sudah ditetapkan oleh dinas propinsi DIY.

Strategi merupakan kata berasal dari Bahasa Latin strategia, yang diartikan sebagai seni penggunaan rencana untuk mencapai tujuan. Strategi pembelajaran menurut Frelbreg \& Driscoll (1992,p.228) dapat digunakan untuk mencapai berbagai tujuan pemberian materi pelajaran pada berbagai tingkatan, untuk siswa yang berbeda, dalm konteks yang berbeda pula. Strategi pembelajaran merupakan cara-cara yang dipilih untuk menyampaikan materi pelajaran dalam lingkungan pembelajaran tertentu, yang meliputi sifat, lingkup, dan urutan kegiatan yang dapat memberikan pengalaman belajar kepada siswa. Dick \& Carey (1996,p.7) berpendapat bahwa strategi pembelajaran tidak hanya terbatas pada prosedur kegiatan, melainkan juga termasuk di dalamnya materi atau paket pembelajaran. Karena itulah strategi pembelajaran terdiri dari semua komponen materi pelajaran dan prosedur yang akan digunakan untuk membantu siswa mencapai tujuan pembelajaran tertentu. Strategi pembelajaran juga dapat diartikan sebagai pola kegiatan pembelajaran yang dipilih dan digunakan guru secara kontekstual, sesuai dengan karakteristik siswa, kondisi sekolah, lingkungan sekitar serta tujuan khusus pembelajaran yang dirumuskan. Perlu adanya kaitan antara strategi pembelajaran dengan tujuan pembelajaran, agar diperoleh langkah-langkah kegiatan pembelajaran yang efektif dan efisien. Strategi pembelajaran terdiri dari 
metode dan teknik (prosedur) yang akan menjamin bahwasiswaakan betul-betul mencapai tujuan pembelajaran.

Strategi pembelajaran bahasa sudah bayak dibicarakan. Berbagai jenis strategi pembelajaran bahasa bisa diterapkan disesuaikan dengan konisi siswa. Hal tersebut seperti yang dikatakan Pringgawidagda (2002, p.104), bahwa ada kecenderungan pembelajaran bahasa daerah di wilayah kota-kota (Jawa Tengah, Jawa Timur, DIY) sebagai bahasa kedua. Hal tersebut karena banyak siswa yang tidak menggunakan bahasa Jawa sebagai bahasa ibu mereka. Berbagai hal melatarbelakangi mengapa mereka tidak diajarkan bahasa Jawa sebagai bahasa ibu mereka salah satunya karena bahasa Jawa yang dirasa sulit. Dengan alasan tersebut orang tua lebih memilih menggunakan bahasa Indonesia sebagai bahasa Ibu anak-anaknya dan menyerahkan pembelajaran bahasa Jawa di sekolah. Alasan tersebut membuat guru semakin bekerja keras memilih strategi agar pembelajaran yang hanya disekolah dalam hitungan menit itu bisa berhasil.

Gulo (2002,pp.11-12) mengatakan bahwa tidak ada strategi yang dikatakan paling baik, tetapi strategi yang sesuai atau lebih efektif untuk digunakan. Suatu strategi bisa dikatakan efektif bila: (1) Daya serap terhadap pembelajaran yang dilakukan mendapatkan prestasi yang tinggi dari individu ataupun kelompok. (2) Perilaku yang sudah ditetapkan dalam tujuan pembelajaran bisa dicapai siswa, dari individu ataupun kelompok. Tetapi, indikator yang sering digunakan sebagai tolak ukur keefektifan strategi ini adalah daya serap. Untuk mengukur dan mengevaluasi tingkat kefektifan strategi ini bisa dilakukan dengan tes prestasi belajar. Ini bisa terlihat dari nilai-nilai ulangan, ulangan tengan semester dan ulangan akhir semester. Strategi yang digunakan guru bahasa jawa di MBS dirasa efektif karena siswa sudah tuntas mencapai Kriteria Ketuntasan Minimal (KKM) nilai bahasa Jawa di MBS.

Dalam penelitian ini akan diuraikan tentang strategi pembelajaran bahasa daerah khususnya bahasa Jawa di SMP Muhammadiyah Boarding School (MBS)Yogyakarta dimana bahasa Jawa sebagai bahasa ibu, bahasa ke dua bahkan sebagai bahasa Asing. Hal tersebut disebabkan karena memang siswa dari MBS sangat heterogen siswanya yang berasal dari Sabang sampai Merauke bahkan dari negara tetangga seperti Thailand dan Malaysia. Selain karena siswa yang heterogen daerah asalnya, background sekolah yang merupakan pondok pesantren modern, menjadikan guru harus lebih kretif dalam memilih strategi pembelajaran, sehingga tidak hanya sekedar pemenuhan kurikulum tetapi ada keselarasan antara tujuan pembelajaran bahasa daerah dengan tujuan dari sekolah secara umum.

\section{METODE PENELITIAN}

Jenis penelitian ini merupakan penelitian lapangan dengan menjadikan data lapangan sebagai acuan utama, sedangkan sifat dari penelitian ini adalah penelitian kualitatif dengan pendekatan studi kasus untuk melihat lebih detail tentang strategi pembelajaran guru bahasa Jawa di SMP Muhammadiyah Boarding School Yogayakarta. Subjek penelitian ini adalah siswa dan guru bahasa Jawa kelas VII di MBS. Objek penelitian ini adalah strategi pembelajaran bahasa Jawa di SMP Muhammadiyah Boarding School Yogayakarta. Penelitian ini menggunakan teknik pengumpulan data yaitu dengan observasi wawancara dan 
dokumentasi. Instrumen dalam penelitian ini adalah peneliti sendiri yang terlibat langsung dalam proses pembelajaran di kelas untuk pengamatan.

Analisis data dilakukan dengan pengumpulan data dan pendataan informasi terkait dengan temuan di lapangan sehingga memudahkan pencatatan dan pendataan terkait dengan temuan di lapangan tanpa harus menunggu proses pengamatan berakhir. Setelah data terkumpul kemudian mereduksi data-data tersebut dengan mengklasifikasi dan kategorisasi terkait dengan strategi pembelajaran bahasa Jawa di SMP Muhammadiyah Boarding School. Reduksi data sudah dilakukan, selanjutnya adalah melakukan penyusunan pokok-pokok temuan secara sistematis yang menjadi fokus kajian penelitian agar makna peristiwanya semakin jelas. Penarikan kesimpulan dengan memperhatikan aspekaspek yang berkaitan dengan strategi pembelajaran bahasa Jawa di SMP Muhammadiyah Boarding School beserta faktor-faktor yang melatarbelakangi penggunaan strategi-strategi tersebut.

Keabsahan data dari hasil penelitian dilakukan dengan meningkatkan kualitas keterlibatan peneliti, pengamtan terus-menerus, triangulasi metode dan sumber, pelibatan teman sejawat, menggunakan referensi dlm bentuk dokumen, rekaman tulisan dan copy-an. Transferabilitas dapat diaplikasikan oleh pemakai penelitian sehingga para pembaca memperoleh gambaran dan pemahaman yang jelas tentang konteks dan fokus penelitian. Dependabilitas dan confirmabilitas dilakukan dengan audit trail berupa komunikasi dengan pembimbing guna membicarakan permasalahan yang dihadapi dalam penelitian berkaitan dengan data yang harus dikumpulkan.

\section{HASIL PENELITIAN DAN PEMBAHASAN}

Penelitian ini menemukan berbagai strategi yang digunakan dalam pembelajaran bahasa Jawa di MBS Yogyakarta. Seperti yang dikatakan (Oxford, 1990,p.8) memberikan definisi yang lebih rinci mengenai strategi belajar sebagai "specific actions taken the learner to make learning easier, faster, move enjoyable, more selfdirected, more effective, and move transferrable to new situations" (tindakan tertentu yang dilakukan oleh pembelajar untuk menjadikan pembelajaaran lebih mudah, cepat, menyenangkan, mandiri, efektif, dan lebih mudah ditransfer dalam suasana yang baru. Dibawah ini adalah beberapa strategi yang digunakan dalam pembelajaran bahasa Jawa yang disesuaikan dengan kondisi di MBS.

Banyak peneliti seperti O'Malley dan Chamot (1990) dan Oxford (1990) yang mengelompokkan strategi belajar menjadi 4 jenis: kognitif, metakognitif, efektif, dan sosial. Strategi kognitif berhubungan dengan daya pikir pembelajar dalam mengolah bahan belajar mengajar. Strategi metakognitif berhubungan dengan taktik atau cara pembelajar untuk menghadapi dan mengelola bahan belajar mengjar. Strategi efektif berhubungan dengan sikap dan perasaan pembelajar dalam menghadapi proses belajar pembelajar. Strategi sosial berhubungan dengan kerjasama pembelajar dengan sejawatnya dalam mencapai tujuan belajar. Pengelompokkan ini tampaknya lebih sederhana, namun lebih jelas batasan-batasannya dan setiap strategi memiliki jenis-jenis kegiatan sendiri.

Terdapat dua cara dalam pemanfaatan strategi belajar bahasa kedua menurut Oxford (1990,p. 14). Pertama adalah strategi belajar langsung (direct strategy) dan strategi belajar tidak langsung (indirect strategy). Strategi pembelajaran 
bahasa secara langsung ialah suatu cara yang digunakan pembelajar dalam pemerolehan, penyimpanan, percobaan, dan pemanfaatan atas informasi yang didapat. Strategi pembelajaran bahasa secara langsung ini terbagi atas tiga jenis yaitu memori, kognitif, dan kompensasi. Kedua strategi belajar secara tidak langsung (indirect strategy) juga memegang peranan penting dalam belajar bahasa kedua. Hal ini disebabkan adanya faktor -faktor yang berhubungan dengan pembelajar pada saat belajar bahasa kedua. Faktor-faktor tersebut berhubungan dengan kognisi, afektif atau perasaan pembelajar, dan faktor sosial pembelajar. Faktor-faktor ini menjadi strategi belajar bahasa kedua yang digunakan dalam pembelajaran bahasa Jawa di MBS. Berikut pemaparan hasil penelitian.

Strategi memori ialah strategi yang digunakan untuk mengingat dan menerima informasi baru. Prosedur kerja sistem memori yaitu: Pertama, hubungan kreasi mental dengan cara mengelompokkan, berhubungan/ perluasan dan menempatkan kata baru dalam konteks. Kedua, menerapkan gambar dan suara dengan penggunaan video pembelajaran, pemetaan semantik, penggunaan kata kunci, dan pemberian suara dalam memori. Ketiga mengulas kembali dengan baik, dengan menjawab pertanyaan. Empat, melakukan kegiatan/ aksi denganmenggunakan respon atau sensasi fisik dan menggunakan teknik mekanik.

Strategi kognitif ialah strategi untuk memahami bahasa dan menghasilkan atau melakukan produksi bahasa. Berikut kerja sistem kognitif: Pertama, melakukan praktik dengan mengulang pelajaran dengan tanya jawab, secara formal melatih dengan sistem suara dan menulis dengan membaca dan membuat kalimat dari materi kosakata dan melatih secara alami dengan berbincang dengan teman sekelas. Kedua, menerima dan mengirim pesan dengan mendapat ide dengan cepat dan menggunakan sumber untuk menerima dan mengirim pesan. Ketiga, menganalisis dan memberi alasan berupa alasan deduktif dengan menjelaskan pengertian, jenis dan contoh dalam materi pembelajaran, menganalisis ekspresiketika menggunakan kata dalam kalimat, menganalisis kontras antar bahasa, dan menerjemahkan cerita berbahasa Jawa dalam bahasa Indonesia. Empat, mengkreasi struktur untuk input dan output dengan mencatat, memperhatikan penjelasan, membaca dari papan tulis, memperhatikan media pembelajaran dan membaca buku.

Strategi kompensasi ialah strategi belajar yang sangat bermanfaat bagi pembelajar yang sedang belajar sedikit tentang bahasa kedua.Sistem kerja strategi kompensasi yaitu: Pertama menebak dengan cerdas denganmenggunakan petunjuk linguistik dan menggunakan petunjuk lain. Kedua melebihi batas dalam bicara dan menulis yang dengan kembali ke topik asal, menerima bantuan, menggunakan tiruan atau isyarat, menghindarim komunikasi sebagian atau total, memilih topik, mengatur atau menduga pesan, memperkaya perbendaharaan kata, dan menggunakan perbendaharaan kata yang memiliki persamaan atau perlawanan arti.

Strategi metakognitif ini menekankan akan pentingnya pembelajar untuk memusatkan konsentrasi belajar bahasa, menyusun dan merencanakan belajar bahasa, dan mengevaluasi cara belajar bahasa tersebut. Berikut ini prosedur sistem kerja strategi metakognitif: Pertama, memusatkan belajar dengan mengulas materi baru dan menghubungkan dengan materi yang sudah dikuasai, 
memberi perhatian terhadap pokok bahasan, dan menunda percakapan atau obrolan dengan orang lain untuk memusatkan pikiran terfokus pada pokok bahasan. Kedua, mengatur dan merencanakan belajar dengan mencari tahu tentang pembelajaran bahasa Jawa dengan bertanya kepada guru dan teman, menentukan tujuan, mengidentifikasi tujuan pembelajaran bahasa Jawa, merencanakan untuk tugas bahasa Jawa, dan mencari kesempatan latihan. Ketiga, mengevaluasi belajar dengan memonitor atau mengawasi diri dan mengevaluasi diri terhadap porses dan hasil belajar.

Strategi afektif ialah strategi kedua dari strategi belajar bahasa secara tidak langsung. Strategi belajar ini mencakup emosi, sikap, motivasi, dan nilai-nilai dalam proses mempelajari bahasa kedua. Prosedur sistem kerja strategi afektif: Pertama, menurunkan kegelisahan dengan menggunakan relaksasi dan tertawa. Dua, menyemangati diri sendiri dengan membuat pernyataan positif dan menghargai diri sendiri. Tiga, mengontrol temperatur emosi dengan mendengarkan gerakan tubuh dan mendiskusikan perasaan dengan orang lain (curhat).

Strategi sosial ialah strategi pembelajaran bahasa secara tidak langsung bahwa peserta didik telah terjun ke dunia sosial. Tanpa disadari, peserta didik telah melakukan kegiatan belajar bahasa kepada orang lain melalui kegitan sosial. Dalam strategi ini sistem kerja strategi sosial yaitu: Pertama, menanyakan pertanyaan dengan menanyakan klarifikasi dan verifikasi dan menanyakan pembetulan. Kedua, bekerja sama dengan orang lain dengan cara bekerjasama dengan kawan sebaya dan bekerjasamadengan pemakai bahasa yang sudah cerdas atau mahir dalam hal ini bertanya kepada guru. Ketiga, memiliki rasa empati kepada orang lain dengan mengembangkan pemahaman budaya Jawa danmenjaga perasaan orang lain.

Dalam penelitian ini ditemukan juga apa saja yang menjadi faktor yang melatarbelakangi pemilihan strateggi pembelajaran menurut Sanjaya (2009,p. 296) yang menjelaskan bahwa yang melatarbelakangi pemilihan strategi pembelajaran yaitu tujuan pembelajaran, materi pembelajaran siswa dan lainnya yang berupa kurikulum, sarana prasarana, waktu dan akses informasi dan komunikasi.

\section{Strategi Memori}

Strategi memori ialah strategi yang digunakan untuk mengingat dan menerima informasi baru. Ada dua syarat untuk memahami bagaimana individu belajar dan bagaimana mereka menerapkan strategi-strategi belajar yaitu dengan mengetahui pentingnya pengetahuan awal atau informasi baru,dan cara otak memproses pengetahuan awal atau informasi baru itu.

Sejumlah ahli spikologi kognitif telah mengembangkan apa yang mereka sebut pandangan pemrosesan informasi (information processing) tentang pembelajaran. Para ahli teori ini sepenuhnya menyandarkan pada komputer sebagai analogi untuk menjelaskan bagaimana otak dan sistem memorinya bekerja. Dari sudut oandang ini, informasi masuk ke dalam otak melalui inderaindera (analog dengan memasukkan data melalui keyboard komputer) dan disimpan sementara di dalam suatu ruang kerja yang disebut memori jangka pendek atau short-term memory (ruang penyimpanan dari sebuah komputer). 
Dari memori jangka pendek data itu kemudian dikirimkan ke memori jangka panjang atau long-term memory (hard disk komputer) dan disimpan sampai dipanggil kembali untuk pengguanaan di kemudian hari (M.Nur 2004, pp.18-19).

Strategi memori ialah strategi yang digunakan untuk mengingat dan menerima informasi baru. Prosedur kerja sistem memori yaitu: Pertama, hubungan kreasi mental dengan cara mengelompokkan, berhubungan/ perluasan dan menempatkan kata baru dalam konteks. Kedua, menerapkan gambar dan suara dengan penggunaan video pembelajaran, pemetaan semantik, penggunaan kata kunci, dan pemberian suara dalam memori. Ketiga mengulas kembali dengan baik, dengan menjawab pertanyaan. Empat, melakukan kegiatan/ aksi denganmenggunakan respon atau sensasi fisik dan menggunakan teknik mekanik.

Strategi belajar memori digunakan oleh pembelajar dengan memanfaatkan pengetahuan dan pengalaman belajar sebelumnya. Strategi belajar ini banyak melibatkan ingatan dan proses pembelajaran yang menggunakan daya ingat. Dalam hubungan kreasi mental, dalam pembelajaran dengan materi yang sudah dipersiapkan guru siswa siap menerima pelajaran tentang kosakata. Kata-kata itu berupa kata sifat, kata benda, bilangan kata kerja, dan sebagainya. Kemudian menerapkan kata tersebut dalam bentuk kalimat. Penggunaan gambar dalam pembelajaran bahasa Jawa di MBS lebih pada audio visual, tidak hanya sekedar mendengar tetapi juga melihat gambar-gambar itu bergerak selakyaknya beraktivitas. Setelah melihat video tersebut siswa menjadi tahu kapan penggunaan kata beserta sikap yang harus dilakukan ketika mengucapkan kata tersebut. Dalam materi unggah-ungguh ketika siswa akan berjalan mendahului atau berjalan di depan orang lain selalu mengucapkan " Ndherek langkung”, frasa tersebut memiliki arti "numpang lewat" . frasa tersebut memiliki makna permintaan ijin atau permisi untuk lewat ketika berjalan di depan banyak orang. Penggunaan frasa tersebut tidak hanya sekedar diucapkan melainkan ada gerakan dengan membungkukkan badan sebagai wujud menghormati untuk orang yang akan didahului atau dilewati.

Dalam strategi yang digunakan ini, siswa tidak hanya sekedar belajar tentang tatakrama orang Jawa ketika berjalan dari ucapannya saja. Dengan melihat, dengan memperhatikan sampai mempraktikan ucapan sekaligus tindakan yang harus dilakukan ketika mengucapkan kalimat tersebut. Begitu juga dengan penggunaan kata-kata lain yang telah dipelajari tentang kosakata dengan ragam ngoko dan krama, siswa akan mengingat dengan mudah penggunaan kata tersebut ketika sudah dibuat dalam fungsi kalimat langsung langsung bahkan pengguaannya dalam keseharian dengan berdialog dengan teman, guru bahkan warga masyarakat sekitar pondok.

\section{Strategi Kognitif}

Strategi kognitif ialah strategi untuk memahami bahasa dan menghasilkan atau melakukan produksi bahasa. Kognitif ialah pemahaman manusia terhadap suatu objek itu berlangsung secara bertahap yang meliputi tahap manipulasi dan tahap interaksi aktif. Setelah manusia bisa memanipulasi objek, kemampuan interaksi aktif manusia berfungsi untuk memantapkan dan memproduksi pengetahuan baru.Secara bertahap, strategi kognitif meliputi terbentuknya konsep 
"kepermanenan objek" dan kemajuan gradual (tahap demi tahap) dari perilaku refleksif ke perilaku yang mengarah kepada tujuan, penggunaan simbol-simbol bahasa untuk menyatakan objek-objek di dunia, perbaikan dalam kemampuan untuk berfikir secara logis, mulai berpikir produksi sebuah bahasa, dan pemikiran berkembang lebih luas, dan disinilah produksi sebuah bahasa dihasilkan (M.Nur, 2004, p.16).

Cara kerja sistem kognitif adalah: Pertama, melakukan praktik dengan mengulang pelajaran melaluitanya jawab, secara formal melatih dengan sistem suara dan menulis dengan membaca dan membuat kalimat dari materi kosakata dan melatih secara alami dengan berbincang dengan teman sekelas. Kedua, menerima dan mengirim pesan dengan mendapat ide dengan cepat dan menggunakan sumber untuk menerima dan mengirim pesan. Ketiga, menganalisis dan memberi alasan berupa alasan deduktif dengan menjelaskan pengertian, jenis dan contoh dalam materi pembelajaran, menganalisis ekspresi ketika menggunakan kata dalam kalimat, menganalisis kontras antar bahasa, dan menerjemahkan cerita berbahasa Jawa dalam bahasa Indonesia. Empat, mengkreasi struktur untuk input dan output dengan mencatat, memperhatikan penjelasan, membaca dari papan tulis, memperhatikan media pembelajaran dan membaca buku.

Strategi kognitif adalahsegala perilaku pembelajar dalam proses belajar mengajar yang behubungan dengan penggunaan daya pikir pembelajar. Strategi ini dapat berwujud berbagai kegiatan. Dalam penelitan, siswamelakukan praktik dengan mengulang pembelajaran sebelumnya tentang "pocapan"dalam bahasa Indonesiaartinya pengucapan dengan berlatih menuliskan kata yang diucapkan dengan benar bagaimana membaca kemudian menulis kata berbahasa Jawa, terutama untuk huruf-huruf Jawa yang hampir sama d-dh, t-th, a-o yang bisa mengubah arti apabila salah dalam dalam penulisan atau pengucapannya. Misalnya, antara kata "lara" yang berarti sakit dan "loro" yang berarti angka dua. Hal tersebut sering diabaikan oleh siswa padahal keduanya memiliki makna berbeda jika pengucapan dan penulisannya juga berbeda.Selain itu, perilaku kognitif yang diharapkan dapat mewakili strategi ini adalah membetulkan kesalahan sendiri, menggunakan gerakan isyarat, melatih mengucapkan kata, menulis dalam buku catatan, membaca dari papan tulis, dan menatap media ajar, selain itu strategi kognitif yang ditunjukkan adalah ketika membaca. Siswa membaca buku atau referensi yang disarankan guru, kemudian menggarisbawahi kata-kata yang dianggap penting atau tidak paham artinya. Untuk kegiatan membaca kemudian menggaris bawahi, sebenarnya ini jarang dilakukan oleh siswa kalaupun dilakukan ini adalah sesuai dengan instruksi dari guru, misalnya siswa diperintahkan untuk menggaris bawahi, kalimat penting yang terdapat dalam buku. Tidak sedikit mereka menulis tentang arti sebuah kata baru bahasa Jawa di buku catatan.

\section{Strategi Kompensasi}

Strategi kompensasi ialah strategi belajar yang sangat bermanfaat bagi pembelajar yang sedang belajar sedikit tentang bahasa kedua. Terkadang, dengan keterbatasan kosakata dan pengetahuan tentang bahasa kedua, pembelajar akan 
panik, tidak dapat bicara atau bahkan sering sekali melihat kamus untuk memastikan kata yang tepat. Sistem kerja strategi kompensasi yaitu: Pertama menebak dengan cerdas denganmenggunakan petunjuk linguistik dan menggunakan petunjuk lain. Kedua melebihi batas dalam bicara dan menulis dengan kembali ke topik asal, menerima bantuan, menggunakan tiruan atau isyarat, menghindari komunikasi sebagian atau total, memilih topik, mengatur atau menduga pesan, memperkaya perbendaharaan kata, dan menggunakan perbendaharaan kata yang memiliki persamaan atau perlawanan arti.

Strategi belajar kompensasi digunakan oleh pembelajar yang telah memiliki keterampilan-keterampilan yang cukup tinggi. Strategi belajar ini biasanya dimanfaatkan untuk menanggulangi beberapa keterbatasan dalam berbahasa. Pembelajar yang mengalami kesulitan dalam menerangkan sesuatu dalam bahasa yang dipelajari, misalnya dapat menggunakan definisi atau terjemahan dalam ujarnya untuk menjaga agar proses berbahasa tetap berjalan. Bahkan, gerakangerakan badan dapat digunakan untuk menutup keterbatasan yang dihadapi. Termasuk dalam jenis strategi belajar ini adalah menentukan atau memilih sendiri topik yang dibicarakan. Bahkan untuk menghindari topik yang sulit juga merupakan strategi dalam kelompok ini.

Jenis strategi ini banyak dilakukan, hal tersebut mengingat tentang bagaimana latar belakang siswa MBS itu sendiri. Kompensasi ini dilakukan selain pada tahap pembelajaran juga pada tahap evaluasi. Pada tahap pembelajaran, penggunanan bahasa tidak konsisten. Addanya alih kode dan campur kode, baik guru ataupun siswa. Penggunaan bahasa Indonesia ini untuk membantu, menekankan, agar materi ini lebih tersampaikan kepada siswa begitupun juga siswa ketika pembelajaran unuk menyampaikan apa yang ingin disampaikan kepada guru. Kadang siswa juga memilih menggunakan bahasa Indonesia dalam menjawab soal, bila sudah tidak mampu mendapatkan kosakata yang diharapkan. Materi pembelajaran juga menjadi pertimbangandengan melihat kemampuan siswa yang baru mempelajari bahasa Jawa. Materi dibuat lebih sederhana bahkan mengganti dengan materi lain yang lebih ringan ketika melihat materi dari kurikulum terlampau sulit untuk mereka yang baru belajar.

\section{Strategi Meta-kognitif}

Strategi metakognisi adalah strategi tidak langsung belajar bahasa kedua. Strategi ini menekankan akan pentingnya pembelajar untuk memusatkan konsentrasi belajar bahasa, menyusun dan merencanakan belajar bahasa, dan mengevaluasi cara belajar bahasa tersebut. Terkadang, pembelajar sibuk dengan materi belajar saja tanpa menyadari bahwa strategi belajarnya seharusnya diubah atau diperbaiki dengan melihat hasil kemajuan belajarnya. Dengan strategi metakognisi ini, pembelajar akan menyadari bahwa strategi belajar bahasanya sudah tepat atau belum. Dalam hal ini pembelajar dapat mengevaluasi sendiri atau dapat berkonsultasi dengan guru atau mentor dalam mengevaluasi hasil belajarnya.

Strategi metakognitif berhubungan dengan berfikir siswa dengan berfikirnya sendiri dan kemampuannya untuk memonitor proses-proses kognitif. Strategi metakognitif meliputi dua-duanya, yaitu pengetahuan tentang kognisi 
dan kemampuan memonitor, mengendalikan, dan mengevaluasi fungsi-fungsi kognitif diri sendiri.Strategi metakognitif ini menekankan akan pentingnya pembelajar untuk memusatkan konsentrasi belajar bahasa, menyusun dan merencanakan belajar bahasa, dan mengevaluasi cara belajar bahasa tersebut. Berikut ini prosedur sistem kerja strategi metakognitif: Pertama, memusatkan belajar dengan mengulas materi baru dan menghubungkan dengan materi yang sudah dikuasai, memberi perhatian terhadap pokok bahasan, dan menunda percakapan atau obrolan dengan orang lain untuk memusatkan pikiran terfokus pada pokok bahasan. Kedua, mengatur dan merencanakan belajar dengan mencari tahu tentang pembelajaran bahasa Jawa dengan bertanya kepada guru dan teman, menentukan tujuan, mengidentifikasi tujuan pembelajaran bahasa Jawa, merencanakan untuk tugas bahasa Jawa, dan mencari kesempatan latihan. Ketiga, mengevaluasi belajar dengan memonitor atau mengawasi diri dan mengevaluasi diri terhadap porses dan hasil belajar.

Strategi meta-kognitif adalah segala perilaku pembelajar yang berhubungan dengan teknik atau cara pembelajar untuk menghadapi dan mengelola bahan belajar mengajar. Dalam penelitian ini, strategi meta-kognitif diwujudkan berbagai macam kegiatan. Memusatkan belajar yang meliputi mengulang materi sebelumnya dan menghubungkan dengan materi yang baru dipelajari. Saat proses guru memberi penjelasan siswa memusatkan perhatian dengan diam memperhatikan. Mengatur dan merencanakan belajar yang meliputi mencari tahu tentang pembelajaran bahasa, mengatur, menentukan tujuan, mengidentifikasi tujuan pembelajaran bahasa (tujuan mendengar/ membaca/ menulis/ berbicara),merencanakan untuk tugas bahasa, dan mencari kesempatan latihan tidak semata-mata dilakukan sendiri oleh siswa. Guru berperan penting dalam proses ini bahwa tujuan mereka belajar bahasa Jawa sebagai media dakwah selain untuk mempelajarai bagaimana kebudayaan masyarakat Jawa. Siswa mengetahui tujuan tersebut mereka bisa menentukan sendiri waktu untuk mereka melatih kemampuan mereka berbahasa Jawa. Mengevaluasi belajar yang meliputi memonitor atau mengawasi diri, dan mengevaluasi diri terhadap porses dan hasil belajar, hal tersebut dilakukan atas bimbingan guru. Keterbukaan guru dalam memberi penilaian kognitif membuat siswa menjadi tahu bagaimana perkembangan kemampuan belajarnya, dengan mengetahui apa yang menjadi kesalahan dan kekurangannya siswa menyadari jika nilai tidak mencapai Kriteria Ketuntasan Minimal (KKM), sudah pasti akan mengikuti remedial.

\section{Strategi Afektif}

Strategi afektif ialah strategi kedua dari strategi belajar bahasa secara tidak langsung. Strategi belajar ini mencakup emosi, sikap, motivasi, dan nilai-nilai dalam proses mempelajari bahasa kedua. Terdapat beberapa cara yang dapat ditempuh oleh pembelajar untuk mencapai hasil yang memuaskan dalam belajar bahasa kedua. Menurut Oxford (1990,p.141) terdapat tiga cara dalam memanfaatkan strategi afektif ini dalam belajar bahasa kedua, yaitu dengan mengurangi kecemasan dengan cara mendengarkan musik, tertawa, dan meditasi setelah belajar bahasa kedua; meningkatkan kepercayaan diri dengan membuat pernyataan -pernyataan positif, menghargai diri sendiri dalam belajar bahasa 
kedua; mengatur suhu emosi sendiri dengan berdiskusi dengan rekan ketika mempunyai masalah, berusaha untuk mendengarkan suara tubuh ketika sudah terlalu lelah dalam belajar bahasa kedua.

Prosedur sistem kerja strategi afektif: Pertama, menurunkan kegelisahan dengan menggunakan relaksasi dan tertawa. Dua, menyemangati diri sendiri dengan membuat pernyataan positif dan menghargai diri sendiri. Tiga, mengontrol temperatur emosi dengan mendengarkan gerakan tubuh dan mendiskusikan perasaan dengan orang lain (curhat). Strategi afektif adalah segala perilaku pembelajar yang berhubungan dengan sikap dan perasaan pembelajar dalam menghadapi proses belajar. Strategi ini lebih lanjut dibagi menjadi dua yaitu afektif positif dan afektif negatif. Strategi afektif positif adalah prilaku pembelajar yang menunjukkan bahwa pembelajar menerima dan menghargai proses belajar mengajar. Strategi afektif negatif adalah prilaku pembelajar yang menunjukkan bahwa pembelajar menolak dan tidak menghargai proses belajar mengajar. Istilah "negatif" yang digunakan di sini tidak mengandung makna buruk. Penolakan pembelajar tehadap proses belajar mengajar harus dipandang sebagai sikap yang "netral",yang tidak berhubungan dengan nilai baik-buruk.

Dalam strategi ini,siswa bahkan guru mengurangi rasa gelisah,jenuh bahkan mengantuk dalam mengiuti proses pembelajaran dengan berbagai cara. Contoh seperti dalam pembelajaran aksara Jawa, siswa dipertotonkan bagaimana sejarah aksara Jawa dengan melihat video cerita tersebut yang dikemas lebih masa kini dalam bentuk kartun. Menonton dengan santai sambil menonton video yang diputarkan. Dengan siswa tertawa, tepuk tangan, kadangkala bersorak karena melihat adegan dalam film kartun tersebut. Tanpa mereka sadari mereka sudah tau bagaimana cerita terbentuknya akasara Jawa dengan melihat video tersebut. Strategi afektif positif diwakili oleh empat prilaku tertawa dengan menunjukkan kesenangan atau kepuasan, tersenyum menunjukkan kepuasan dan menunjukkan kesenangan karena hal-hal yang lucu menyenangkan. Kadangkala siswa mengalami rasa jenuh dalam proses pembelajaran. Suasana kelas yang panas membuat siswa menjadi kurang bersemangat. Salah satu strategi yang digunakan guru adalah dengan membuat pembelajaran yang menarik perhatian siswa selain dengan melihat video kadangkala guru diminta bercerita. Ketika guru bercerita strategi afektif negatif nampak dari perilaku siswa dengan menunjukkan kebingungan karena tidak paham bahasanya, mengeluh, tidak memperhatikan guru, berbicara dengan teman sebangku di luar relavansi belajar, dan menunjukkan sikap masa bodoh dengan tidur di kelas.

\section{Strategi Sosial}

Strategi sosial ialah strategi pembelajaran bahasa secara tidak langsung bahwa peserta didik telah terjun ke dunia sosial. Tanpa disadari, peserta didik telah melakukan kegiatan belajar bahasa kepada orang lain melalui kegitan sosial. Sebagaimana prinsip strategi pembelajaran di atas sebagai berikut bahwa peserta didik melakukan suatu aktivitas belajar bahasa kedua atau bahasa target dengan penuh menyenangkan dan efektif dalam kondisi baru. Peserta didik akan mendapatkan dua kemampuan saat melakukan strategi sosial yang berupa kemampuan belajar bahasa dan kemampuan bersosial. Strategi sosial ialah 
strategi pembelajaran bahasa secara tidak langsung bahwa peserta didik telah terjun ke dunia sosial. Tanpa disadari, peserta didik telah melakukan kegiatan belajar bahasa kepada orang lain melalui kegitan sosial. Dalam strategi ini sistem kerja strategi sosial yaitu: Pertama, menanyakan pertanyaan dengan menanyakan klarifikasi dan verifikasi dan menanyakan pembetulan. Kedua, bekerja sama dengan orang lain dengan cara bekerjasama dengan kawan sebaya dan bekerjasamadengan pemakai bahasa yang sudah cerdas atau mahir dalam hal ini bertanya kepada guru. Ketiga, memiliki rasa empati kepada orang lain dengan mengembangkan pemahaman budaya Jawa dan menjaga perasaan orang lain.

Strategi sosial ini sering terjadi antara siswa yang mampu berbahasa Jawa dengan siwa yang tidak menggunakan bahasa Jawa sebagai bahasa keseharian mereka. Entah itu hanya bercanda dalam kelas, bertanya kata yang sulit, bahkan untuk menerjemahkan kalimat perintah yang diberikan oleh guru. Siswa juga memiliki rasa kepedulian terhadap teman yang nampak tidak paham dengan apa yang diperintahkan guru. Siswa yang berbahasa ibu bahasa Jawa menjadi tutor sebaya untuk siswa asing. Tugas mereka hanya membantu menerjemahkan kata sulit atau menjelaskan kalimat guru dengan bahasa Indonesia. Namun keterbatasan kemampuan siswa jika merasa ragu dalam menerjemahkan kalimat, siswa tersebut meminta klarifikasi dan verifikasi kepada guru agar tidak salah dalam memberi arti kalimat kepada temannya.

Strategi sosial tidak hanya sekedar berkaitan dengan bagaimana siswa belajar tetapi cara mereka bergaul dengan teman ketika di kelas. Dalam kelas mereka terlatih untuk sportif dalam bersaing mendapatkan hasil yang terbaik, sekedar mengapresiasi teman yang mendapatkan nilai terbaik atau untuk teman dari luar Jawa yang memiliki kemampuan menjawab pertanyaan dari guru menggunakan bahasa Jawa, diberikan tepuk tangan sebagai bentuk pujian. Tidak jarang juga siswa saling bersorak untuk menertawakan teman yang menggunakan dialek ngapak dalam pembelajaran. Peran guru dalam situasi ini dengan menjadikan kata yang dianggap lucu sebagai objek pembelajaran bahwa meskipun sama menggunakan bahasa Jawa tetapi setiap daerah memiliki ciri khas yang berbeda dengan daerah lainnya.

Pendidik mempunyai peran penting dalam menentukan strategi belajar mengajar yang paling tepat dan baik karena pendidik lebih tahu keaadaan dan kondisi anak didik serta segala aspek yang berhubungan dengan proses belajar mengajar. Sanjaya (2009, p. 296) menyatakan bahwa sebelum memilih strategi belajar mengajar ada bebrapa hal yang harus diperhatikan agar pemilihan strategi belajar mengajar dapat optimal dan efektif. Pendidik mempunya peranan penting ketika menentukan strategi pembelajaran yang tepat dan baik untuk siswa, karena pendidik lebih mengerti suasana dan keadaan siswa beserta semua aspek yang berhubungan dengan proses pembelajaran. Strategi yang digunakan di MBS ini memperhatikan beberapa hal,sehingga pembelajaran ini dapat optimal dan efektif.

\section{Tujuan}

Setiap kegiatan belajar mengajar tentu mempunyai tujuan tertentu yang ingin dicapai. Semakin kompleks tujuan yang ingin dicapai maka semakin rumit juga strategi yang harus dirancang. Di bawah ini ada beberapa pertanyaan yang 
dapat diajukan sehubungan dengan tujuan kegiatan belajar mengajar: Apakah tujuan pembelajaran yang ingin dicapai berkenaan dengan aspek kognitif, afektif atau psikomotorik? Pertanyaan ini mengandung pengertian bahwa setiap jenis tujuan yang dirumuskan akan berimplikasi pada rancangan suatu strategi.

Tujuan pembelajaran bahasa Jawa di MBS ini agar siswa mengerti tentang budaya masyarakat Jawa khususnya tentang tatakrama dalam pergaulan. Selain itu dengan siswa mempelajari bahasa Jawa bisa menjadi sarana dalam mereka berdakwah di masyarakat, terlebih kepada masyarakat Jawa. Dari tujuan tersebut aspek kognitif, afektif dan psikomotorik menjadi bagian yang tidak bisa terpisahkan karena guru tidak hanya sekedar mengajarkan pengertian dari tatakrama tetapi juga bagaimana bertatakrama sebagai bagian dari masyarakat Jawa.

\section{Materi}

Materi atau pengalaman belajar merupakan pertimbangan kedua yang harus diperhatikan. Materi pelajaran yang sederhana misalnya, materi pelajaran berupa data yang harus dihafal, maka pengalaman belajar pun cukup sederhana juga, mungkin siswa hanya dituntut untuk mendengarkan, mencatat dan menghafalnya. Dengan demikian strategi yang digunakan juga sederhana.Berbeda ketika materi pelajaran berupa generalisasi, teori, atau keterampilan, maka pengalaman belajar pun harus dirancang sedemikian rupa sehingga materipelajaran dan pengalaman belajar dapat mencapai tujuan yang diharapkan.

Materi atau pengalaman belajar juga menjadi hal yang harus diperhatikan. Relevan atau tidak materi pembelajaran tersebut disampaikan, dilihat dari usia dan posisi bahasa Jawa itu sesniri bagi siswa, karena tidak semua menjadikan bahasa Jawa sebagai bahasa ibu mereka. Dalam penelitian Permana, P.C \& Nurhayati, E. (2014, p.52) kaitannya dengan relevansi serat Kalatidha dalam pembelajaran bahasa Jawa menunjukkan bahwa diksi serat Kalatidha tidak relevan apabila digunakan sebagai materi ajar tingkat SMP. Dalam penelitian tersebut subjeknya adalah siswa SMP kelas IX yang merasa terlalu berat untuk siswa SMP. Hampir sama perasalah dengan di SMP MBS, banyak materi yang dianggap berat, apalagi mengingat ada siswa dari luar Jawa dan luar negeri yang sangat asing dengan bahasa Jawa. Ditambah lagi bahwa di sekolah-sekolah tertentu materi pembelajaran bahasa Jawa sering menjadi perdebatan sengit antara guru dengan pihak sekolah. Hal tersebut disebabkan adanya pemikiran bahwa tradisi sering bertentangan dengan akidah. Dalam hal ini ada materi kebudayaan tentang tradisi masyarakat Jawa yang dikhawatirkan dapat mempengaruhi akidah siswa jika diajarkan. Karena alasan itulahsalah satu cara yang dilakukan guru adalah membuat bahan pembelajaran dalam bentuk modul yang berdasarkan kebutuhan siswa dan latar belakang sekolah SMP MBS yang berbasis sekolah pesantren.

Materi pembelajaran bahasa Jawa di MBS, khususnya kelas VII yang dibuat sebagai kelas penyetaraan bahasa. Materi yang dibuat benar-benar dari dasar, seperti dalam semester ganjil dengan memperbanyak materi kosakata. Berawal dari jenis-jenis kata, bilangan, bagian tubuh dan membuat kalimat. Dalam hal ini dua ragam bahasa yang digunakan dalam pembelajaran yaitu bahasa ngoko dan krama untuk pembelajaran unggah-ungguh. Materi ini sengaja dibuat demikian 
agar siswa memiliki kemampuan yang sama terlebih dahulu dalam hal perbendaharaan kata. Pengunaan kata dalam pembelajaran ini lebih implementatif, yaitu kata-kata yang bisa digunakan langsung berdasarkan unggah-ungguh dalam masyarakat Jawa. Dialog dan wacana dalam modul dibuat dalam temasehari-hari yang bernafaskan Islam sesuai dengan basis sekolah tersebut.Semester genap, guru sudah menggunakan materi yang sesuai dengan buku pembelajaran siswa sesuai dengan kurikulum dari dinas, meskipun sedikit lambat namun materi di semester genap bisa diikuti siswa.

\section{Siswa}

Siswa adalah individu yang unik, yang memiliki perbedaan, tidak ada siswa yang sama. Walaupunsecara fisik hampir sama, namun pasti ada hal-hal tertentu yang berbeda, misalnya perbedaan dari sudut minat, bakat, kemampuan bahkan gaya belajar. Dengan demikian strategi belajar mengajar yang dirancang dsesuaikan dengan keadaan siswa. Beberapa pertanyaan rancangan strategi ditinjau dari sudut siswa diantaranya: Apakah strategi yang digunakan sesuai dengan tingkat kematangan siswa? Apakah strategi yang digunakan itu sesuai dengan minat, bakat dan kondisi siswa?Apakah strategi yang dipilih sesuai dengan gaya belajar siswa?

Siswa adalah individu yang unik, berbeda satu dengan yang lain. Kalau dari fisik terlihat sama, pastinya ada hal yang membedakan antara minant, bakat, kemampuan dan cara belajar. Dengan begitu strategi pembelajaran yang digunakan disesuaikan dengan keadaan siswa. Karakteristik siswa MBS, dibagi menjadi empat jenis: (1) siswa pribumi yang termotivasi, (2) siswa pribumi yang tidak termotivasi, (3) siswa luar daerah \& asing yang termotivasi, (4) siswa luar daerah $\&$ asing yang tidak termotivasi. Klasifikasi tersebut hasil dari pengamatan guru yang mengajar di sana. Siswa dari Jawa yang merasa senang dengan pembelajaran bahasa Jawa karena merasa rindu dengan bahasa ibunya, di saat pelajaran menjadi waktu yang bebas berbicara dengan bahasanya sehari-hari di rumah. Siswa yang berasal dari Jawa tapi merasa tidak bersemangat dalam mengikuti pelajaran karena pelajaran di semester ganjil sama seperti pelajaran waktu mereka duduk di Sekolah Dasar, merasa bosan karena tidak ada perkembangan dalam segi keilmuan membuat mereka menjadi terkesan menggampangkan. Siswa dari luar Jawa yang suka dengan pelajaran bahasa Jawa karena merasa tertarik dengan berbagai budaya dari Jawa. Dengan belajar bahasa Jawa mereka menjadi sangat terbantu saat berada di luar pondok dalam berkomunikasi dengan warga sekitar. Sedangkan untuk siswa luar Jawa yang tidak bersemangat belajar bahasa Jawa karena merasa bahwa itu tidak akan mereka dalam keseharian merekaketika sudah kembali ke tanah kelahiran masing-masing.

Keadaan siswa MBS yang heterogen dilihat dari daerah asalnya, ini menjadi pemikiran guru bagaimana agar siswa mengerti dan bisa mengikuti proses pembelajaran. Bahasa Jawa di sana ada yang menjadi bahasa ibu, bahasa kedua, bahkan bahasa asing. Bagi siswa yang bahasa Jawa sebagai bahasa kedua dan asing merasa kesulitan, karena kata-kata dalam bahasa Jawa itu lebih banyak dan penggunaannya harus disesuaikan kapan dan dengan siapa ketika berbicara. Karena alasan demikian, untuk kelas VII ini dijadikan sebagai kelas penyetaraan 
bahasa, mengingat tentang keberagaman daerah asal siswa yang pastinya memiliki pengetahuan yang berbeda-beda pula tentang budaya Jawa.

\section{Kurikulum}

Pada dasarnya kurikulum dalam MBS menggunakan dua kurikulum, yaitu kurikulum dari dinas dan kurikulumpondok. Kurikulum KTSP adalah kurikulum dinas yang digunakan untu kelas VII MBS. Berdasarkan ketentuan tersebut, dalam pembelajaran bahasa Jawa juga berpedoman dengan silabus bahasa Jawa yang berlaku di Yogyakarta. Sampai penelitian ini dilakasanakan memang belum ada kurikulum bahasa Jawa yang mengatur tentang sistem pembelajaran di pesantren, apalagi dengan kondisi siswa yang heterogen dari daerah asalnya. Kurikulum untuk pembelajaran bahasa Jawa sebagai bahasa kedua juga belum ada. Guru melakukan pengembangan silabus dengan musyawarah guru bidang studi bahasa Jawa di MBS sehingga mendapatkan hasil bahwa mereka tetap berpedoman pada silabus yang berlaku hanya dilakukan pengembangan dan memberikan inovasi yang berkaitan dengan basis MBS itu sendiri yang berbasis pesantren.

\section{Sarana Prasarana}

Sarana dan prasarana sebagai pendukung dan pembantu dalam pembelajaran. Siswa diharapkan mampu mengembangkan pengetahuannya dengan menggunakan sarana dan prasarana yang ada. Ketidakseimbangan anatara jumlah siswa dengan perpustakaan yang tidak bisa membuat siswa leluasa mempelajari secara mandiri tentang ilmu yang dipelajari karena jumlahnya sangat terbatas. Penggunaan lab komputer yang tidak secara maksimal juga membuat tidak bisa mendapatkan referensi yang lebih banyak. Di dalam kelas sudah ada LCD, jadi keterbatasan referensi itu bisa diatasi dengan guru memberikan contoh melalui gambar atau video yang ditampilkan untuk menarik perhatian siswa dan diharapkan lebih mendukung pemahaman siswa tentang materi yang dipelajari.

\section{Waktu Pembelajaran}

Waktu menjadi pertimbangan khusus dalam proses pembelajaran. Bagaimana guru mangatur waktu yang ada menjadi cukup dalam menyelesaikan proses pembelajaran. Tidak seimbang antara banyaknya materi dengan materi yang sudah ada di kurikulum menjadi permasalahan ketika waktu yang disediakan lebih sedikit dari yang semestinya. Ketika melihat silabus dari dinas, dengan waktu pembelajaran dua jam setiap minggu di MBS hanya satu jam pembelajaran. Karena demikian materipun juga harus disesuaikan dengan waktunya. Apalagi kalau ada hal yang tak terduga, siswa yang sulit dikendalikan akan semakin menambah waktu. Pertimbangan waktu ini pula yang menjadikan pembelajaran bahasa Jawa di MBS berbeda dengan sekolah umum, karena tidak semua materi diajarkan dan hanya memperdalam materi yang berkaitan dengan tujuan awal pembelajaran bahasa Jawa di MBS.

\section{Akses Informasi Dan Komunikasi}

Sekoah dengan berbasis pesantren tidak seleluasa sekolah umum. Siswasiswi di pesantren berada dalam lingkungan pondok dan sekolah. Mereka 
bergiatan penuh dalam sekolah dan pondok sehingga akses untuk berinteraksi dengan lingkungan pondok tidak sebebas anak-anak yang bersekolah umum. Siswa di MBS dua minggu sekali mendapat jadwal keluaran di hari Jumat. Hari libur dimanfaatkan siswa untuk pulang ke rumah masing-masing atau dijenguk oleh keluarga yang datang ke pondok. Keadaan yang demikian, waktu siswa banyak dihabiskan di sekolah dan pondok. Komunikasi dengan warga sekeliling pondok pun juga terbatas. Siswa tidak diperkenankan membawa handphone, menggunkan komputer ketika ada hubungannya dengan pelajaran TIK. Siswa bisa tetap tahu tentang kabar ,atau informasi dari luar dengan membaca koran atau majalah yang ada di sekolah.

Dalam berkomunikasi di MBS penggunaan bahasa bersifat lokatif. Siswa di sekolah secara umum menggunakan bahasa Indonesia, di tempat tertentu sepeti kantin atau koprasi siswa menggunakan bahasa Inggris dan ketika di pondok siswa menggunakan bahasa Arab atau Inggris. Ruang penggunaan bahasa daerah dalam hal ini adalah bahasa Jawa, hanya terbatas ketika waktu pembelajaran bahasa Jawa saja. Adanya mahkamah bahasa ketika siswa menggunakan bahasa daerah akan ada sangsi yang harus mereka terima. Hal tersebut pula yang memberi pengaruh kepada semangat belajar bahasa Jawa siswa, karena sudah merasa takut jika mendapatkan hukuman.

Pertimbangan lainnya dalam hal ini adalah pertimbangan ditinjau dari strategi itu sendiri, sesbab begitu banyak strategi yang dapat dipilih dalam proses belajar mengajar. Seperti dalam mencapai tujuan pembelajaran tidak hanya cukup menggunakan satu strategi saja, karena itu lah strategi-strategi saling berkaitan satu dengan yang lainya. Pemilihan strategi yang digunakan dalam pembelajaran pasti sudah menjadi pertimbangan bagaimana kefektifan serta efisiensinya dalam kelas tersebut, sehingga menjadi strategi yang tepat dilakukan untuk kondisi tertentu seperti yang dilakukan di MBS.

\section{PENUTUP}

Tujuan pembelajaran bahasa Jawa di MBS ini agar siswa mengerti tentang budaya masyarakat Jawa khususnya tentang tatakrama dalam pergaulan. Selain itu dengan siswa mempelajari bahasa Jawa bisa menjadi sarana dalam mereka berdakwah. Materi pembelajaran merupakan materi yang sudah ditetapkan dalam kurikulum bahasa Jawa di Yogyakarta hanya saja dibuat dalam nuansa lebih Islami dan lebih sederhana mengingat bahwa siswa siswa MBS yang heterogen yaitu siswa yang berasal dari Jawa, luar Jawa dan luar negeri. Kurikulum KTSPyang guru gunakan dengan melakukan pengembangan silabus melaluimusyawarah guru bidang studi bahasa Jawa di MBS sehingga mendapatkan hasil bahwa mereka tetap berpedoman pada silabus yang berlaku hanya dilakukan pengembangan dan memberikan inovasi yang berkaitan dengan basis MBS itu sendiri yang berbasis pesantren.Sarana prasarana seperti perpustakaan \&laboratorium komputer yang belum dipergunakan secara maksimal dan juga akses informasi dan komunikasi yang terbatas karena berada dalam lingkungan pondok dengan segala peraturan yang ada didalamnya membuat siswa yang hanya belajar bahasa Jawa satu jam pembelajaran kurang dalam pengembangan pengetahuan mereka. Tujuan pembelajaran, siswa, kurikulum, 
sarana prasarana, materi dan waktu, akses informasi dan komunikasi menjadi faktor pemilihan strategi tersebut.

\section{DAFTAR PUSTAKA}

Badruzzaman, Muhammad. (2015). Kurikulum dan Implementasi Pembelajaran Bahasa Arab di Pesantren (Studi Kasus di Pondok Pesantren Nurul Ummah Kota Gede dan Muhammadiyah Boarding School Yogyakarta, Prambanan, Sleman, Yogyakarta). Tesis magister, tidak diterbitkan, Universitas Islam Negeri Sunan Kalijaga, Yogyakarta

Dick, W \& Carey, L.(1990).The Systematic Design of Instruction.Third Edition, Harper Collins Publishers.

Frelbreg, H.J \& Driscoll,A. (1992). Universal Teachimg Strategies.Boston:Allyn $\&$ Bacon

Gubernur. (2011).Peraturan Daerah Provinsi Daerah Istimewa Yogyakarta No 5, Tahun 2011, tentang Pengelolaan dan Penyelenggaraan Pendidikan Berbasis Budaya

Gulo, W. (2002). Strategi Belajar Mengajar. Jakarta: PT Grasindo

Gubernur. (2013).Peraturan Gubernur Daerah Istimewa Yogyakarta No 64, Tahun 2013, tentang Mata Pelajaran Bahasa Jawa Sebagai Muatan Lokal Wajib

Nur, M. (2004). Strategi-strategi Belajar.Surabaya: Unipress

O"e Malley, J. M., \& A. Chamot. (1990). Learning Strategies in Second Language Acquisition.Cambridge: Cambridge University Press.

Oxford, R. L. (1990). Language Learning Strategies: What Every Teacher Should Know.New York: Newbury House Publishers.

Permana, P.C \& Nurhayati, E. (2014). Ragam Bahasa Serat Kalatidha Serta Relevansinya dalam Pembelajaran Bahasa Jawa Siswa SMP Negeri 7 Yogyakarta. Program Studi Linguistik Terapan Program Pascasarjana Universitas Negeri Yogyakarta., Volume 1, Nomor 1, Mei 2014. ISSN:2406-9213, hal 39-53

Pringgawidagda, S. (2002). Strategi Penguasaan Berbahasa. Yogyakarta: Adicita Karya Nusa

Sanjaya, W. (2009). Pembelajaran dalam Implementasi Kurikulum Berbasis Kompetensi. Jakarta: Kencana Prenada Group. 
